\title{
Correction: Total Lymphocyte Count as surrogate marker for CD4 Cell Count in HIV-Infected Individuals in Gondar University Hospital, Northwest Ethiopia
}

Yitayih Wondimeneh, Getachew Ferede*, Gizachew Yismaw, Dagnachew Muluye, Meseret Alem and Fanaye Asfaw

\section{Correction}

After publication of this work [1], we noted that we inadvertently failed to include the complete list of all coauthors. The full list of authors has now been added and the Authors' contributions and competing interests section modified accordingly.

\section{Competing interests}

Mr. Meseret and Ms. Fanaye have held supervisions, consultancies and follow up while we are conducting our research. The other authors declare no conflicts of interest.

\section{Authors' contributions}

YW: Participated in conception and design of the study, data collection, analysis and interpretations of the findings, reviewed the manuscript; GF: Participated in conception and design of the study, analysis and interpretations of the findings, drafting the manuscript and write up; GY: Supervision of the study, analysis and interpretations of the findings, reviewed the manuscript; DM: Participated in analysis and interpretations of the findings, reviewed the manuscript; MA: supervision of the study, consultation, follow up and reviewed the manuscript; FA: supervision of the study, consultation, follow up and reviewed the manuscript

Received: 2 January 2013 Accepted: 2 January 2013

Published: 4 January 2013

\section{References}

1. Yitayih W, Getachew F, Gizachew Y, Dagnachew M: Total lymphocyte count as surrogate marker for CD4 cell count in HIV-infected individuals in Gondar University Hospital, North West Ethiopia. AIDS Res Ther 2012, 9:21.

\section{doi:10.1186/1742-6405-10-2}

Cite this article as: Wondimeneh et al: Correction: Total Lymphocyte Count as surrogate marker for CD4 Cell Count in HIV-Infected Individuals in Gondar University Hospital, Northwest Ethiopia. AIDS Research and Therapy 2013 10:2.

* Correspondence: get29f@gmail.com

School of Biomedical and Laboratory Sciences, College of Medicine and Health Sciences, University of Gondar, P.O. Box 196, Gondar, Ethiopia

\section{Submit your next manuscript to BioMed Central and take full advantage of:}

- Convenient online submission

- Thorough peer review

- No space constraints or color figure charges

- Immediate publication on acceptance

- Inclusion in PubMed, CAS, Scopus and Google Scholar

- Research which is freely available for redistribution

\section{() Biomed Central}

